medRxiv preprint doi: https://doi.org/10.1101/2021.07.23.21260280; this version posted July 25, 2021. The copyright holder for this preprint (which was not certified by peer review) is the author/funder, who has granted medRxiv a license to display the preprint in perpetuity. It is made available under a CC-BY-NC-ND 4.0 International license .

\title{
A Multi-Site Analysis of the Prevalence of Food Security in the United States, before and during the COVID-19 Pandemic
}

Authors and Institutions:

\begin{tabular}{|c|c|}
\hline Meredith T. Niles & University of Vermont \\
\hline Alyssa W Beavers & Wayne State University \\
\hline Lauren A. Clay & D'Youville College \\
\hline Marcelle M. Dougan & San José State University \\
\hline Giselle A. Pignotti & San José State University \\
\hline Stephanie Rogus & New Mexico State University \\
\hline Mateja R. Savoie-Roskos & Utah State University \\
\hline Rachel E. Schattman & University of Maine, Orono \\
\hline Rachel M. Zack & The Greater Boston Food Bank \\
\hline Francesco Acciai & Arizona State University \\
\hline Deanne Allegro & Auburn University at Montgomery \\
\hline Emily H. Belarmino & University of Vermont \\
\hline Farryl Bertmann & University of Vermont \\
\hline Erin Biehl & Johns Hopkins University \\
\hline Nick Birk & The Greater Boston Food Bank \\
\hline Jessica Bishop-Royse & DePaul University \\
\hline Christine Bozlak & University at Albany- State University of New York \\
\hline Brianna Bradley & Johns Hopkins University \\
\hline Barrett P. Brenton & Binghamton University \\
\hline James Buszkiewicz & University of Washington \\
\hline Brittney N. Cavaliere & Connecticut Food Bank/Foodshare \\
\hline Young Cho & University of Wisconsin-Milwaukee \\
\hline Eric M. Clark & University of Vermont \\
\hline Kathryn Coakley & University of New Mexico \\
\hline Jeanne Coffin-Schmitt & Cornell University \\
\hline Sarah M. Collier & University of Washington \\
\hline Casey Coombs & Utah State University \\
\hline Anne Dressel & University of Wisconsin-Milwaukee \\
\hline Adam Drewnowski & University of Washington \\
\hline Tom Evans & University of Arizona \\
\hline Beth J Feingold & University at Albany- State University of New York \\
\hline Lauren Fiechtner & MassGeneral Hospital for Children \\
\hline Kathryn J. Fiorella & Cornell University \\
\hline Katie Funderburk & Auburn University \\
\hline $\begin{array}{l}\text { Preety Gadhoke } \\
\text { Diana Gonzales- }\end{array}$ & St. John's University (at the time of study administration) \\
\hline Pacheco & University of New Mexico \\
\hline Amelia Greiner Safi & Cornell University \\
\hline Sen $\mathrm{Gu}$ & St. John's University \\
\hline Karla L. Hanson & Cornell University \\
\hline
\end{tabular}




\begin{tabular}{|c|c|}
\hline Amy Harley & University of Wisconsin-Milwaukee \\
\hline Kaitlyn Harper & Johns Hopkins University \\
\hline Akiko S. Hosler & University at Albany- State University of New York \\
\hline Alan Ismach & University of Washington \\
\hline Anna Josephson & University of Arizona \\
\hline Linnea Laestadius & University of Wisconsin-Milwaukee \\
\hline Heidi LeBlanc & Utah State University \\
\hline Laura R. Lewis & Washington State University \\
\hline Michelle M Litton & Wayne State University \\
\hline Katie S. Martin & Connecticut Food Bank/Foodshare \\
\hline Shadai Martin & New Mexico State University \\
\hline Sarah Martinelli & Arizona State University \\
\hline John Mazzeo & DePaul University \\
\hline Scott C. Merrill & University of Vermont \\
\hline Roni Neff & Johns Hopkins University \\
\hline Esther Nguyen & University of Washington \\
\hline Punam Ohri-Vachaspati & Arizona State University \\
\hline Abigail Orbe & Connecticut Food Bank/Foodshare \\
\hline Jennifer J. Otten & University of Washington \\
\hline Sondra Parmer & Auburn University \\
\hline Salome Pemberton & Hunter College, City University of New York \\
\hline Zain Al Abdeen Qusair & DePaul University \\
\hline Victoria Rivkina & DePaul University \\
\hline Joelle Robinson & Johns Hopkins University \\
\hline Chelsea M. Rose & University of Washington \\
\hline Saloumeh Sadeghzadeh & Binghamton University \\
\hline Brinda Sivaramakrishnan & Tacoma Community College \\
\hline Mariana Torres Arroyo & University at Albany- State University of New York \\
\hline McKenna Voorhees & Utah State University \\
\hline Kathryn Yerxa & University of Maine, Orono \\
\hline
\end{tabular}

\section{Abstract}

Background. The COVID-19 pandemic profoundly affected food systems including food security.

$4 \quad$ Understanding how the COVID-19 pandemic impacted food security is important to provide

5 support, and identify long-term impacts and needs.

Objective. Our team- the National Food Access and COVID research Team (NFACT) was formed to assess food security over different U.S. study sites throughout the pandemic, using common instruments and measurements. Here we present results from 18 study sites across 1015 states and nationally over the first year of the COVID-19 pandemic. 
medRxiv preprint doi: https://doi.org/10.1101/2021.07.23.21260280; this version posted July 25, 2021. The copyright holder for this preprint (which was not certified by peer review) is the author/funder, who has granted medRxiv a license to display the preprint in perpetuity.

It is made available under a CC-BY-NC-ND 4.0 International license .

across the sites throughout the first year of the pandemic, representing 22 separate surveys. Sampling methods for each study site were convenience, representative, or high-risk targeted. Food security was measured using the USDA six-item module. Food security prevalence was analyzed using analysis of variance by sampling method to statistically significant differences.

Results. In total, more than 27,000 people responded to the surveys. We find higher prevalence of food insecurity (low or very low food security) since the COVID-19 pandemic, as compared to before the pandemic. In nearly all study sites, we find higher prevalence of food insecurity among Black, Indigenous, and People of Color (BIPOC), households with children, and those with job disruptions. We also demonstrate lingering food insecurity, with high or increased prevalence over time in sites with repeat surveys. We find no statistically significant differences between convenience and representative surveys, but statistically higher prevalence of food insecurity among high-risk compared to convenience surveys.

Conclusions. This comprehensive multi-study site effort demonstrates higher prevalence of food insecurity since the beginning of the COVID-19 pandemic, which in multiple survey sites continues throughout the first year of the pandemic. These impacts were prevalent for certain demographic groups, and most pronounced for surveys targeting high-risk populations.

Keywords: food security, COVID-19, survey sampling, food insecurity, high-risk,

\section{Introduction}

The coronavirus disease 2019 (COVID-19) was declared a pandemic by the World Health

37 Organization in March 2020 (1), with widespread impact across the United States (U.S.) and globally. As of April 12, 2021 , the U.S. had over $20 \%$ of confirmed cases and about $19 \%$ of the COVID-19-related deaths globally (2). Furthermore, COVID-19 was the third leading cause of death in the U.S. in 2020 (3).

42 The pandemic caused major disruptions to the U.S. economy, food system, and overall health

43 and wellbeing of Americans. The unemployment rate in the U.S. reached an unprecedented

44 high of $14.8 \%$ in April 2020 (4), with job disruptions concentrated in low-paying jobs,

45 disproportionately affecting Black, Indigenous, and People of Color (BIPOC) (5). Although the 
medRxiv preprint doi: https://doi.org/10.1101/2021.07.23.21260280; this version posted July 25, 2021. The copyright holder for this preprint (which was not certified by peer review) is the author/funder, who has granted medRxiv a license to display the preprint in perpetuity.

It is made available under a CC-BY-NC-ND 4.0 International license .

unemployment rate declined to $6.7 \%$ in December 2020, the economic effects of the pandemic are likely to persist for years, consistent with the Great Recession of 2008 (6). The need to social distance and quarantine to contain disease spread led to stockpiling, placing a strain on the food supply chain, which was unable to adequately respond to the pandemic, resulting in food access concerns for many Americans (7). This, in combination with widespread disruption in employment, increased food-related hardship for many Americans, particularly those most vulnerable to economic disruption (8).

Disasters, like hurricanes, and public health emergencies like the COVID-19 pandemic disrupt built and social environments, and their impacts persist long after they occur (9-11). Disasters tend to impact housing stability, household composition, and financial obligations, which can limit resources for food and lead to food-related hardship (12). Groups most vulnerable to disasters were disproportionately affected during the pandemic, including low-income households, single-headed households with children, adults living alone, and Black- and Hispanic-headed households (13-15). The COVID-19 pandemic magnified the health disparities that exist among low-income households, who were already more likely to struggle to meet basic needs (15).

Food insecurity, or the inability to consistently obtain enough, desirable, varied, and nutritious foods (16), is heightened during disasters and emergencies (17, 18). Emergency nutrition response aims to assist affected individuals; however coordinating enough high-quality food remains a challenge in a post-disaster setting $(19,20)$. Quickly assessing food insecurity to inform pandemic relief efforts was a challenging task; for instance, the national food insecurity statistics for 2020 from the U.S. Census Bureau, measured using the USDA's Household Food Security Survey Module (HFSS), will not be released until September 2021 (21). As a result, agencies, organizations, and researchers deployed surveys and produced estimates to 
medRxiv preprint doi: https://doi.org/10.1101/2021.07.23.21260280; this version posted July 25, 2021. The copyright holder for this preprint (which was not certified by peer review) is the author/funder, who has granted medRxiv a license to display the preprint in perpetuity.

It is made available under a CC-BY-NC-ND 4.0 International license .

72 determine the impact of the pandemic on food insecurity. For example, the U.S. Census

73 Bureau released the Household Pulse Survey that captures food insufficiency and Feeding

74 America released projected food insecurity prevalence for 2020 and 2021 based on changes in

75 unemployment and poverty (21-23). Nationally representative surveys found that food

76 insecurity drastically increased at the onset of the COVID-19 pandemic, from $11 \%$ in 2018 up to

$7738 \%$ in March 2020 (24). This is especially high considering the impact of economic downturn

78 during the Great Recession of 2008 when food insecurity peaked at much lower $15 \%$ in 2011

$79(13,25)$. In addition, households that were food insecure prior to the pandemic were more likely

80 to have their situations exacerbated due to less job flexibility, higher risk of job loss/furlough,

81 and fewer resources/support to allow for complying with social distancing recommendations

82 (15). Although the early months of the pandemic may have been the peak of food insecurity

83 and insufficiency, higher than usual rates have persisted as the COVID-19 pandemic continues

$84(26)$.

Despite several early surveys assessing food insecurity during the COVID-19 pandemic, and

87 continued efforts to measure food insufficiency through the Census Household Pulse Survey,

88 there have been few collaborative efforts to monitor and measure food insecurity across diverse

89 geographic and social contexts, and to compare data. In May 2020, a national collaboration of

90 researchers - The National Food Access and COVID Research Team (NFACT) - was formed to

91 examine COVID-19 impacts on food access, food insecurity, and the overall food system. This

92 study reports the findings of this collaborative effort, with data from 18 study sites including a

93 nationally representative sample, to better understand food insecurity over diverse regions and

94 timeframes. The study examined overall levels of food insecurity, as well as food insecurity

95 among households with children, households that experienced job disruption, and participants

96 identifying as BIPOC. We further assessed how different survey implementation methods 
medRxiv preprint doi: https://doi.org/10.1101/2021.07.23.21260280; this version posted July 25, 2021. The copyright holder for this preprint (which was not certified by peer review) is the author/funder, who has granted medRxiv a license to display the preprint in perpetuity.

It is made available under a CC-BY-NC-ND 4.0 International license .

97 associate with different levels of food insecurity, and report results from multiple time points

98 within the same study site, based on data availability.

\section{Methods}

101 Survey Development

102 A survey instrument, known as the NFACT Survey Version 1.0 (27) was developed in March

103 2020. This survey was developed in consultation with key stakeholders in the state of Vermont,

104 where it was first implemented, and drew from the existing literature on food security and food

105 access. Where possible, validated questions and instruments were used. The survey was

106 piloted in Vermont, with 25 adult residents in late March, and validation methods (e.g. Cronbach

107 alpha, factor analysis) were used to test the internal validity of questions with key constructs

108 (alpha $>0.70)(28)$. A second version of the survey was released in May 2020 to reflect

109 changes in the COVID-19 context (29) and include new questions. The surveys included

110 questions on food access, food security, food purchasing, food assistance program

111 participation, dietary intake, perceptions of COVID-19, and individual and household

112 sociodemographic characteristics. The questions utilized in this study were included in both

113 surveys and across study sites.

NFACT Study Sites and Data Collection

116 NFACT represents 18 study sites across 15 states, as well as a national sample (Figure 1).

117 NFACT study sites distributed the NFACT surveys (in whole or part) online pursuing one of

118 three sampling strategies: 1) Convenience sampling in partnership with community

119 organizations, stakeholders, social media, and/or news media, which are not representative of a

120 state population (ten sites); 2) Quota sampling using survey panels administered by Qualtrics

121 (Provo, UT), a survey research company, in which the quotas aimed to achieve state

122 representation on some characteristics (e.g. race, ethnicity, income) (eight sites); or 3) Quota or 
medRxiv preprint doi: https://doi.org/10.1101/2021.07.23.21260280; this version posted July 25, 2021. The copyright holder for this preprint (which was not certified by peer review) is the author/funder, who has granted medRxiv a license to display the preprint in perpetuity.

It is made available under a CC-BY-NC-ND 4.0 International license .

convenience sampling in which certain high-risk populations (e.g. low-income, BIPOC, or Supplemental Nutrition Assistance Program (SNAP) participants) were targeted (six sites). In some cases where high-risk populations were targeted, these groups were oversampled to ensure adequate representation in the overall study sample. Table 1 provides specific details about the sampling strategies, target populations, representation of the data, and survey fielding dates. Potential participants under age 18 were excluded across all study sites. All study sites administered the survey in English; in Arizona, California-Bay Area, Maine, Massachusetts, Nationally, NY-Capital Region, New Mexico, and Utah, surveys were also administered in Spanish. IRB approval was obtained by each study site prior to commencing data collection.

\section{Measures}

Food security was assessed using the United States Department of Agriculture (USDA) 6-item Short Form Food Security Survey Module (30) which is designed to identify households with food insecurity. In most sites, participants were asked to complete 6-items about the year before COVID-19 and since the COVID-19 pandemic began in March 2020, though a few sites only asked these questions since the COVID-19 pandemic began. In some more recent surveys (i.e. Massachusetts, NY-Central/Upstate and the second Washington survey) and in Michigan respondents answered questions about food security in the past 30 days, which is validated through the USDA module. Following standard USDA scoring, a score of 2-6 was categorized as food insecure (30). It is important to note that the pre-pandemic food security responses were retrospective, and were answered at the same time as the questions about current food security. Households with children were determined with a question about household composition by age. Households with any members ages 0-17 years were classified as a household with children. Job disruption was assessed by asking participants if their household experienced a job disruption since the start of the pandemic, including job loss, furlough, or loss of hours/income reduction, categories which were not mutually exclusive. 
medRxiv preprint doi: https://doi.org/10.1101/2021.07.23.21260280; this version posted July 25, 2021. The copyright holder for this preprint (which was not certified by peer review) is the author/funder, who has granted medRxiv a license to display the preprint in perpetuity.

It is made available under a CC-BY-NC-ND 4.0 International license .

149 Participants indicating any negative job impact were categorized as experiencing a job disruption. BIPOC classification was determined based on survey questions about race and

151 ethnicity. Participants indicating any race or ethnicity besides non-Hispanic White (NHW) were

152 classified as BIPOC. Participants indicating NHW were classified as such and Hispanic of any 153 race were classified as Hispanic.

Data aggregation and analysis

156 Food insecurity prevalence (overall and for specific populations of interest) by study site and 157 survey were aggregated into a single dataset for analysis in Stata 16.0 (31). While we primarily 158 report descriptive statistics of the results across the multiple sites, we also used analysis of 159 variance (ANOVA) with Scheffe multiple comparison tests (32) to assess whether there are 160 statistically significant differences in prevalence of food insecurity (overall and for key sub161 populations) between surveys based on the three different sampling techniques (i.e. convenience, representative, and high-risk). We report $p$ values $<0.05$ as statistically significant

163 in the results.

\section{Results}

Respondent Characteristics

167 The sample included 27,168 adults from across the U.S. with data on food insecurity. The racial 168 and ethnic make-up of the sample overall was $70.0 \% \mathrm{NHW}$, and $28.6 \%$ BIPOC, with $1.4 \%$ of 169 respondents not identifying race or ethnicity. Among BIPOC respondents, $8.0 \%$ identified as 170 non-Hispanic Black, 11.9\% as Hispanic, and 8.1\% other races or multiracial (Table 2). Given

171 the diversity of NFACT study sites, including their sample size and demographic make-up, the 172 number of respondents with demographic characteristics or life experiences (e.g. job disruption

173 or children in the household) varied across study sites. There was a large variation in the 174 proportion of BIPOC respondents across study sites, because of differences in population 
medRxiv preprint doi: https://doi.org/10.1101/2021.07.23.21260280; this version posted July 25, 2021. The copyright holder for this preprint (which was not certified by peer review) is the author/funder, who has granted medRxiv a license to display the preprint in perpetuity.

It is made available under a CC-BY-NC-ND 4.0 International license .

175 composition, but also because some study sites oversampled BIPOC respondents. Slightly

176 over $40 \%$ of respondents (40.6\%) had children in the household, ranging from $19.2 \%$ of

177 households in Maine to $85.6 \%$ of households in the California, Bay Area. Among all

178 respondents, 35.3\% had experienced some type of job disruption since the COVID-19

179 pandemic began, ranging from a low of $10.8 \%$ of respondents in a second Washington State

180 survey in early 2021 , to $76.5 \%$ of respondents in a NY Capital Region survey in January and

181 February 2021. Among representative samples, the range varied from $37.6 \%$ in the national

182 sample to $61.3 \%$ in the NY- Capital region in October-January.

184 Overall Prevalence of Food Insecurity

185 We found higher levels of food insecurity reported since the COVID-19 pandemic began, as compared to reported for the pre-COVID-19 pandemic period. This finding was consistent in all

18720 sites that asked about food insecurity both before and during the COVID-19 pandemic

188 (Figure 2), with the exception of the New Mexico site (where no change was found). The

189 prevalence of food insecurity across study sites during the COVID-19 pandemic ranged from

$19010.8 \%$ in a Central/Upstate New York convenience survey from October-December 2020 (which

191 asked about the last 30 days), to $73.9 \%$ in a New York City high-risk survey in July/August 2020

192 which oversampled BIPOC, low-income respondents. Among states that represented state

193 characteristics, food insecurity prevalence ranged from $28.8 \%$ in Maryland to $36.2 \%$ in

194 Wisconsin since the start of the COVID-19 pandemic. In sites that gathered data on the time

195 periods both before and during the COVID-19 pandemic, the rate of increase ranged from $0 \%$ in

196 New Mexico to a 65\% increase among respondents in the California Bay Area. We found that

197 both convenience and representative samples had significantly lower prevalence of food

198 insecurity both before and since the COVID-19 pandemic, as compared to surveys targeting

199 high-risk populations, though the percent change did not significantly differ across survey

200 sample type (Table 3). 
medRxiv preprint doi: https://doi.org/10.1101/2021.07.23.21260280; this version posted July 25, 2021. The copyright holder for this preprint (which was not certified by peer review) is the author/funder, who has granted medRxiv a license to display the preprint in perpetuity.

It is made available under a CC-BY-NC-ND 4.0 International license .

Prevalence of Food Insecurity Among BIPOC Respondents

203 In all survey sites that collected data on food insecurity before and during the COVID-19

204 pandemic, we found that food insecurity increased for BIPOC respondents since the onset of

205 the COVID-19 pandemic, with the exception of New Mexico. Furthermore, we found that the

206 prevalence of food insecurity among BIPOC respondents during the COVID-19 pandemic was

207 higher than the overall prevalence of food insecurity in the majority of study sites (Figure 3);

208 however, it is worth noting that this was also true for pre-COVID-19 food insecurity. The highest

209 percent increase in food insecurity was identified in the California Bay Area (54.2\% increase in

210 food insecurity among BIPOC respondents). However, the highest prevalence of food insecurity

211 during the COVID-19 pandemic among BIPOC respondents was identified in the NY Capital

212 Region (83.8\%). We found the prevalence of BIPOC food insecurity during the COVID-19

213 pandemic was significantly different $(p=0.048)$ for convenience $(40.2 \%)$ versus high-risk $(55.1 \%)$

214 survey types.

216 Furthermore, we disaggregated race and ethnicity data when a particular survey had at least 30

217 respondents identifying within a specific race or ethnic group (Figure 4). This additional

218 breakdown further highlights disparities in food insecurity across many study sites among

219 BIPOC respondents, as compared to NHW respondents. For example, while the majority of

220 surveys found the prevalence of food insecurity was higher for BIPOC respondents both before

221 and during the COVID-19 pandemic, the opposite is true of NHW respondents (i.e. the majority

222 of surveys found the prevalence of food insecurity among NHW respondents before and during

223 the COVID-19 pandemic was lower than the site's overall food insecurity).

225 Prevalence of Food Insecurity Among Households with Children 
medRxiv preprint doi: https://doi.org/10.1101/2021.07.23.21260280; this version posted July 25, 2021. The copyright holder for this preprint (which was not certified by peer review) is the author/funder, who has granted medRxiv a license to display the preprint in perpetuity.

It is made available under a CC-BY-NC-ND 4.0 International license .

226 In all but one survey (New Mexico) with data on food insecurity before and during the COVID-19

227 pandemic, food insecurity increased among households with children (Figure 5). The highest

228 reported percent change was in Massachusetts (a 62.1\% increase), while the overall highest

229 prevalence during the COVID-19 pandemic was $69.3 \%$ food insecurity among households with

230 children in a Utah survey focused on SNAP participants. In surveys representative of the state

231 population, the prevalence of food insecurity among households with children ranged from

$23241.7 \%$ in Vermont in August/September 2020 to 56\% in Arizona. Convenience surveys had

233 statistically lower food insecurity prevalence as compared to high-risk survey populations both

234 before the COVID-19 pandemic $(p=0.042)$, and during the COVID-19 pandemic $(p=0.003)$

235 (Table 3).

236

237 Prevalence of Food Insecurity Among Respondents Experiencing Job Disruption

238 Food insecurity during the COVID-19 pandemic was higher in all surveys and study sites among

239 respondents facing a job disruption, as compared to the overall prevalence of food insecurity in

240 those sites (Figure 6). The range of food insecurity among respondents with job disruptions

241 ranged from $21.5 \%$ in Central/Upstate New York up to 77.2\% in New York City among all

242 surveys. Among surveys with state-wide representative samples on some characteristics, the

243 prevalence of food insecurity for those with job disruptions ranged from $38.7 \%$ in Vermont in

244 August/September 2020 to $59.8 \%$ in Wisconsin. Convenience surveys had statistically lower

245 food insecurity prevalence as compared to high-risk survey populations for any job disruption

$246(p=0.003)$, job loss $(p=0.003)$, and reduction in hours $(p=0.036)$ (Table 3$)$.

248 Discussion

249 In this study, food insecurity was assessed in multiple sites using a common measurement

250 instrument. Key trends in food insecurity were highly consistent among research sites, albeit

251 with some significant differences in magnitude depending on survey type. This study utilized 
medRxiv preprint doi: https://doi.org/10.1101/2021.07.23.21260280; this version posted July 25, 2021. The copyright holder for this preprint (which was not certified by peer review) is the author/funder, who has granted medRxiv a license to display the preprint in perpetuity. It is made available under a CC-BY-NC-ND 4.0 International license .

252 three different sampling methods (representative, convenience, and targeted high-risk

253 populations), allowing us to compare results between both study sites and sampling strategies.

254 Notably, there were no statistically significant differences in our findings between convenience

255 and representative samples, though high risk populations were consistently more likely to report

256 food insecurity than those recruited through convenience samples. Nearly all study sites that

257 assessed both current and pre-COVID-19 food insecurity found a higher prevalence of food

258 insecurity during the COVID-19 pandemic as compared with before the COVID-19 pandemic.

259 Furthermore, the majority of surveys and sites found higher prevalence among BIPOC

260 respondents as compared to the overall food insecurity prevalence and that of NHW

261 respondents in the same area. All but one survey found higher prevalence of food insecurity for

262 households with children during the COVID-19 pandemic as compared to the overall food

263 insecurity prevalence in a given site, and all surveys found higher prevalence of food insecurity

264 among respondents reporting job disruptions compared to those with no job disruptions.

265 Importantly, among study sites that conducted repeated surveys, all found continued increase in

266 food insecurity as the pandemic continued, demonstrating the ongoing and escalating effects of

267 the COVID-19 pandemic. Below we further elaborate on three key findings, and discuss their

268 implications for future programming and policy.

269 First, food insecurity increased across nearly all research sites between the pre- and during-

270 pandemic periods. These results are consistent with several other national surveys examining

271 the impact of COVID-19 on food insecurity. For example, data from the Census Household

272 Pulse Survey and the COVID Impact Survey used probability sampling to obtain nationally

273 representative samples. In the COVID Impact Survey, data collected in early April 2020 was

274 extended using models to show that the overall prevalence of food insecurity was more than

275 double the predicted rate (33). These same researchers found similar estimates of food

276 insecurity increases using data from the Census Household Pulse Survey (34). The NFACT 
medRxiv preprint doi: https://doi.org/10.1101/2021.07.23.21260280; this version posted July 25, 2021. The copyright holder for this preprint (which was not certified by peer review) is the author/funder, who has granted medRxiv a license to display the preprint in perpetuity.

It is made available under a CC-BY-NC-ND 4.0 International license .

277 survey results support these findings across study sites, where direct data collection has

278 occurred (as opposed to modelled results). Notably, NFACT sites that utilized a representative

279 high-risk sampling approach were more likely than surveys using a convenience or

280 representative sample to document higher prevalence of food insecurity since the onset of the

281 COVID-19 pandemic. These results suggest that targeted oversampling of high-risk populations

282 is likely to detect higher food insecurity outcomes, an important finding for future surveys and

283 methodologies. Furthermore, when assessing overall food insecurity before or during the

284 COVID-19 pandemic there were no statistically significant differences in food insecurity

285 prevalence between convenience and representative sampling approaches. Among all survey

286 approaches there were no significant differences in the percent change of prevalence of food

287 insecurity, suggesting that the rate of change was fairly consistent across all survey types.

288 These results provide important findings for researchers who must balance different priorities

289 when determining a sampling approach in the future (e.g. cost, timeframe for data collection,

290 ability to represent data at a state-level).

291 It should also be noted that our results show clear differences in food insecurity in different U.S.

292 regions. These differences may be partially attributed to problems in the food supply-chain and

293 community purchasing behavior (i.e. stockpiling), especially at the beginning of the pandemic

294 (33). Another likely cause for variation is the inconsistent national approach to pandemic

295 related restrictions such as stay-at-home orders, restrictions on businesses, and quarantine

296 requirements. Variation in state response to the threat of rising food insecurity is best

297 exemplified in state waivers authorized through SNAP and the Women, Infants and Children

298 (WIC) program and administered through the USDA Food and Nutrition Services (FNS).

299 Specifically, states had discretion about which benefits and waivers to request. While some

300 states made repeated requests for a wide range of allowances authorized by Congress, others

301 requested only a few $(35,36)$. It is likely that variation in states' applications of extra benefits 
medRxiv preprint doi: https://doi.org/10.1101/2021.07.23.21260280; this version posted July 25, 2021. The copyright holder for this preprint (which was not certified by peer review) is the author/funder, who has granted medRxiv a license to display the preprint in perpetuity.

It is made available under a CC-BY-NC-ND 4.0 International license .

302 and temporary waivers influenced differences in food insecurity across our study sites. We 303 suggest that future research examine the relative effects of extra benefits and waivers granted

304 to states, and their influence on both programmatic enrollment and food security outcomes.

305 Second, our study found that some populations have experienced higher rates of food insecurity

306 since the COVID-19 pandemic. Consistent with recent studies $(33,37)$, BIPOC populations

307 reported higher rates of food insecurity than NHW respondents in nearly all NFACT study sites

308 both before and since the onset of the COVID-19 pandemic. Moreover, the three sampling

309 approaches used by NFACT sites found strikingly similar results. There was no statistical

310 difference between sampling strategies with the exception of convenience and targeted high-

311 risk approaches, specifically when addressing food insecurity among BIPOC respondents

312 during the COVID-19 pandemic. Several other national surveys using professional survey

313 platforms (Qualtrics and Turk Prime) have similarly found higher food insecurity rates among

314 Black and Hispanic respondents compared with NHW respondents $(15,24)$. The only study to

315 provide food insecurity data for Native American respondents found that this population also has

316 a higher rate of food insecurity than NHW populations since the beginning of the pandemic (24).

317 Our research and the work of others $(38,39)$ clearly shows that the short-term effects of the

318 pandemic expose underlying racial and economic inequalities, but also highlights that BIPOC

319 respondents faced higher prevalence of food insecurity before the COVID-19 pandemic. As a

320 result, strategic policy interventions that include short-term relief and long-term programmatic

321 efforts to support underserved individuals, households, and communities is needed (38).

322 As well, our research also found that the pandemic has disproportionately affected households

323 with children. While it is estimated that the overall prevalence of food insecurity doubled in the

324 early days of the pandemic, it is estimated that food insecurity among households with children

325 tripled during that time period (37). Again, our analysis showed few differences in our results by

326 sampling strategy, with these differences being limited to comparing convenience and high-risk 
medRxiv preprint doi: https://doi.org/10.1101/2021.07.23.21260280; this version posted July 25, 2021. The copyright holder for this preprint (which was not certified by peer review) is the author/funder, who has granted medRxiv a license to display the preprint in perpetuity. It is made available under a CC-BY-NC-ND 4.0 International license .

327 approaches. Several other studies support our findings, showing consistently that households 328 with children are experiencing high levels of food insecurity during the COVID-19 pandemic (15, 329 24).

330 One likely contributor to this trend was the shift to online education, which increased challenges

331 for families that depended on free or reduced price school meals. While federal support such as 332 the Pandemic EBT (P-EBT) program provided additional benefits to families who normally would 333 qualify for these free and reduced-price meals (40), additional hurdles in accessing school 334 meals were reported. For example, the national NFACT survey conducted in the summer of 3352020 found that participation in the school meals program dropped during the beginning of the 336 pandemic. Further, between 45 and 55\% of survey respondents who utilized school meal pick337 ups during the pandemic reported difficulties with availability of delivery, meal pick-up sites 338 being open, and the quantity of food provided (41). Compounding these challenges, low income 339 families with children were more likely to lose income during the COVID-19 pandemic compared 340 to households without children (40). These findings strongly suggest a need for increased 341 support for school food programs, enabling these important programs to ensure that meals 342 reach families in need. Similarly, NFACT sites universally found higher prevalence of food 343 insecurity among households that experienced job or income loss during the pandemic 344 compared to households with no change in employment status, a finding aligned with other 345 recent research $(15,24,42)$.

346 Third, several of our sites conducted repeated surveys, providing insights into the prevalence of 347 food insecurity over time, both within and across regions. Four NFACT study sites have 348 conducted more than one round of surveys (New York City, New York Capital Region, Vermont, 349 and Washington state), while more recent surveys (Massachusetts and the second Washington 350 state survey) were designed to elucidate respondent experiences with food insecurity within the 351 past 30-days, providing a more current understanding of food insecurity prevalence. All follow- 
medRxiv preprint doi: https://doi.org/10.1101/2021.07.23.21260280; this version posted July 25, 2021. The copyright holder for this preprint (which was not certified by peer review) is the author/funder, who has granted medRxiv a license to display the preprint in perpetuity. It is made available under a CC-BY-NC-ND 4.0 International license .

352 up studies found an increasing prevalence of food security as the pandemic continues, with 353 each additional survey demonstrating higher prevalence of food insecurity. All of these rounds

354 of surveys measured food insecurity since the COVID-19 pandemic began, suggesting that 355 additional numbers of individuals continue to become food insecure, even after the initial 356 impacts of COVID-19 have been felt. Likewise, the recent NFACT Massachusetts survey, 357 measuring food insecurity prevalence in the last 30 days, found that nearly $30 \%$ of respondents 358 were classified as food insecure at the end of 2020. This prevalence is significantly higher than 359 the pre-pandemic level of $8.4 \%$ for this state (13), though it should be noted the pre-pandemic 360 level for Massachusetts respondents was much higher than observed pre-pandemic levels.

361 This evidence corroborates other studies suggesting that food insecurity levels are likely to 362 persist above pre-pandemic levels for an extended period of time as occurred after the Great 363 Recession and past disasters (13, 17, 20). As noted by Hernandez and Holtzclaw (43), the 364 combined impact of a pandemic and a recession are unique in modern memory. However, the 365 slow recovery from the 2008 Great Recession in the United States is instructive. It took eleven 366 years for food insecurity levels to return to pre-recession levels after the Great Recession;

367 according to national data, food insecurity went from $11.1 \%$ in 2007 to $14.6 \%$ in 2008 , reaching 368 a peak of $14.9 \%$ in 2011 , and back to $11.1 \%$ only in 2018 (13). Similarly, high levels of food 369 insecurity were observed up to five years following other disasters, such as after Hurricanes 370 Katrina and Harvey $(20,44)$. Besides factors such as age, race/ethnicity, and income, other 371 factors such as support systems, community and generalized self-efficacy are also critical when 372 addressing food insecurity in a post-disaster context. A 5-year follow-up study on Hurricane 373 Katrina revealed that post-disaster food insecurity levels were associated with poor physical and 374 mental health, as well as low social support, generalized self-efficacy, and sense of community $375(17,44)$. Considering that the pandemic has disproportionately affected racial and ethnic 376 minorities, these populations are likely to experience higher levels of food insecurity and be 
medRxiv preprint doi: https://doi.org/10.1101/2021.07.23.21260280; this version posted July 25, 2021. The copyright holder for this preprint (which was not certified by peer review) is the author/funder, who has granted medRxiv a license to display the preprint in perpetuity.

It is made available under a CC-BY-NC-ND 4.0 International license .

377 affected by its long-lasting health effects even after the economy recovers. Taken together,

378 these results suggest that the impact of COVID-19 on food security in the U.S. is far from over,

379 and additional support systems and policies will be necessary to continue to alleviate the long-

380 term impacts of the global pandemic and recession.

Limitations

383 In presenting our results, we recognize two key limitations. First, research that requires

384 participants to report eating or food-related behaviors is challenged by both recall and social

385 desirability bias (45). Retrospectively asking participants about food insecurity has been shown

386 to lead to overestimation of pre-COVID prevalence of food insecurity (34), suggesting our study

387 may contain similar overestimations. However, we try to address this potential limitation by

388 reporting percent change between pre and during COVID-19 food security, in addition to

389 absolute prevalence of food insecurity, though if the overall pre-pandemic levels of food

390 insecurity are lower, our absolute food insecurity prevalence is likely underestimated. While

391 there has been some skepticism about the high prevalence of food insecurity reported since the

392 COVID-19 pandemic began, our results confirm this high prevalence while providing a more

393 robust measure to benchmark changes. Second, surveys across all research sites included in

394 this study were administered online, limiting respondents to those with computer skills and

395 internet access. This potentially introduced a barrier for some (though not all) elderly or low-

396 income potential respondents $(46,47)$, as well as those living in rural areas without reliable

397 internet (48). Our study employed a number of methods to overcome this challenge across

398 different sampling strategies. These strategies included partnering with non-profit and

399 community organizations as well as government assistance programs to advertise the survey,

400 and seeking economic representation through sampling targets. Notably, our results show no

401 statistically significant difference between sites using convenience and representative samples,

402 indicating that even for study sites that employed a convenience sampling approach, this 
medRxiv preprint doi: https://doi.org/10.1101/2021.07.23.21260280; this version posted July 25, 2021. The copyright holder for this preprint (which was not certified by peer review) is the author/funder, who has granted medRxiv a license to display the preprint in perpetuity.

It is made available under a CC-BY-NC-ND 4.0 International license .

potential bias did not have a significant influence on our findings. While differences did emerge when representative and targeted high-risk samples were compared, we argue that this shows

405 the importance of purposeful sampling in target communities.

A number of U.S. studies have explored the impact of COVID-19 on food insecurity prevalence

408 since the beginning of the COVID-19 pandemic, though most have been national samples, 409 modelling efforts, or single site-specific studies. Here, we report the results from a nationwide 410 collaborative effort across 18 study sites and a nationally representative sample, including 22 411 surveys since the beginning of the COVID-19 pandemic. The scale of our work provides data 412 from more than 27,000 people, and more completely demonstrates the economic hardship the

413 COVID-19 pandemic has had for many people. Consistent increases in food insecurity are 414 prevalent, as well as further evidence that the pandemic has exacerbated racial and ethnic 415 disparities in food insecurity that existed prior to the pandemic. Surveys conducted in study 416 sites more than once also demonstrate an increasing prevalence of food insecurity since the

417 COVID-19 pandemic began, and more recent studies reaffirm that high prevalence of food 418 insecurity, compared to before the COVID-19 pandemic, continues. These findings point to the 419 clear continued need for additional programmatic and policy assistance to provide food 420 insecurity and economic relief. Our future work will continue to conduct additional surveys and 421 comparative analysis to quantify changes in food access, food security, and food assistance use 422 as the U.S. recovers from the COVID-19 pandemic.

\section{Acknowledgements:}

426 (NFACT), which is implementing common measurements and tools across study sites in the

427 US. NFACT is a national collaboration of researchers committed to rigorous, comparative, and 428 timely food access research during the time of COVID. We do this through collaborative, open 
medRxiv preprint doi: https://doi.org/10.1101/2021.07.23.21260280; this version posted July 25, 2021. The copyright holder for this preprint (which was not certified by peer review) is the author/funder, who has granted medRxiv a license to display the preprint in perpetuity. It is made available under a CC-BY-NC-ND 4.0 International license .

access research that prioritizes communication to key decision-makers while building our

430 scientific understanding of food system behaviors and policies.

432 We are grateful to the Nutrition and Obesity Policy Research and Evaluation Network 433 (NOPREN) for their support of the ad-hoc COVID-19 Food Security Surveys subgroup that 434 shared insights and surveys relevant to this project. We thank Christi Sherlock at The University 435 of Vermont for her assistance with project management.

\section{Conflicts of Interest}

438 The Authors declare no conflicts of interest.

Funding support:

Alabama: No funding to report.

Arizona: This project was supported by a COVID-19 seed grant from the College of Health Solutions, Arizona State University.

California-Bay Area: This project was supported by the College of Health and Human Sciences, San Jose State University.

Chicago/Illinois: This project was supported by the College of Liberal Arts and Social Sciences, DePaul University

Connecticut: Generous funding was provided to Foodshare by the Hunger to Health Collaboratory.

Maine: We would like to thank the University of Maine School of Food and Agriculture and the George J. Mitchell Center for Sustainability Solutions for their financial support.

Maryland: This research was supported by a Directed Research grant from the Johns Hopkins Center for a Livable Future.

Massachusetts: Funding for The Greater Boston Food Bank team was provided by the Hunger to Health Collaboratory. 
medRxiv preprint doi: https://doi.org/10.1101/2021.07.23.21260280; this version posted July 25, 2021. The copyright holder for this preprint (which was not certified by peer review) is the author/funder, who has granted medRxiv a license to display the preprint in perpetuity. It is made available under a CC-BY-NC-ND 4.0 International license .

Michigan: Funding was provided from Wayne State University faculty startup funds.

National: This research was supported by the College of Health Solutions, Arizona State University with support from the college's COVID-19 seed grant and the university's Investigator Research Funds; the University of Arizona College of Agriculture and Life Sciences Rapid COVID-19 seed grant; a Directed Research grant from the Johns Hopkins Center for a Livable Future; and the University of Vermont, the College of Agriculture and Life Sciences, the Gund Institute for Environment, Office of the Vice President of Research, and the UVM ARS Food Systems Research Center.

New York City: Special thanks to the Vincentian Institute for Social Action for sponsoring both studies.

NY State: Funded by the Natural Hazards Center, Quick Response Grant. The Quick Response program is based on work supported by the National Science Foundation (Award \#1635593). Any opinions, findings, conclusions, or recommendations expressed in this material are those of the author(s) and do not necessarily reflect the views of NSF or the Natural Hazards Center.

NY Capital Region: Funding for the Qualtrics Panel Survey was provided by the Foundation for Food and Agriculture Research. Funding for the non-Qualtrics Panel Survey was provided by UAlbany President's COVID-19 MHD Engaged Researchers Seed Funding Program.

NY Central/Upstate: This work was supported by a Cornell Atkinson Center COVID-19 Rapid Response Fund award.

Utah: We would like to thank the Utah Create Better Health Program, Utah State University Extension, and the Utah Department of Workforce Services for their support and assistance with this project.

Vermont: Funding was provided by The University of Vermont College of Agriculture and Life Sciences and Office of the Vice President of Research, The Gund Institute for Environment, and the UVM ARS Food Systems Research Center. 
medRxiv preprint doi: https://doi.org/10.1101/2021.07.23.21260280; this version posted July 25, 2021. The copyright holder for this preprint (which was not certified by peer review) is the author/funder, who has granted medRxiv a license to display the preprint in perpetuity.

It is made available under a CC-BY-NC-ND 4.0 International license .

Washington: The WAFOOD survey team wishes to thank the UW Population Health Initiative (UWPHI), the UW School of Public Health (UWSPH), and the Department of Epidemiology for their support.

State Specific Acknowledgements

441 Alabama: We thank Auburn University at Montgomery, the Alabama Cooperative Extension

442 System at Auburn University, county Supplemental Nutrition Assistance Program Educators, the

443 Alabama Department of Public Health, End Child Hunger in Alabama and the Montgomery Area

444 Food Bank for assisting in dissemination of the survey.

445 Arizona: We thank all the members of the ASU Food policy and environment research group as

446 well as Dr. Aggie $\mathrm{J}$ Yellow Horse for their helpful feedback on the survey instrument. We also

447 would like to thank Marina Acosta Ortiz for her assistance with the translation of the survey. This

448 project was supported by a COVID-19 seed grant from the College of

449 Health Solutions, Arizona State University.

450 California-Bay Area: We wish to thank the study participants for their time and dedication in

451 completing the survey. Thank you also to our community partners for helping distribute the

452 survey to potential participants. This project was supported by the College of Health and Human

453 Sciences, San Jose State University.

454 Chicago/IIlinois: This project was supported by the College of Liberal Arts and Social

455 Sciences, DePaul University

456 Connecticut: Generous funding was provided to Foodshare by the Hunger to Health

457 Collaboratory.

458 Maine: We would like to thank the University of Maine School of Food and Agriculture and the

459 George J. Mitchell Center for Sustainability Solutions for their financial support.

460 Maryland: This research was supported by a Directed Research grant from the Johns Hopkins

461 Center for a Livable Future. 
medRxiv preprint doi: https://doi.org/10.1101/2021.07.23.21260280; this version posted July 25, 2021. The copyright holder for this preprint (which was not certified by peer review) is the author/funder, who has granted medRxiv a license to display the preprint in perpetuity.

It is made available under a CC-BY-NC-ND 4.0 International license .

Massachusetts: Funding for The Greater Boston Food Bank team was provided by the Hunger to Health Collaboratory.

464 Michigan: Funding was provided from Wayne State University faculty startup funds.

465 National: This research was supported by the College of Health Solutions, Arizona State

466 University with support from the college's COVID-19 seed grant and the university's Investigator

467 Research Funds; the University of Arizona College of Agriculture and Life Sciences Rapid

468 COVID-19 seed grant; a Directed Research grant from the Johns Hopkins Center for a Livable

469 Future; and the University of Vermont, the College of Agriculture and Life Sciences, the Gund

470 Institute for Environment, Office of the Vice President of Research, and the UVM ARS Food

471 Systems Research Center.

472 New Mexico: We would like to thank the many community organizations and institutions that

473 assisted with the dissemination of our survey, particularly New Mexico First, New Mexico

474 Thrives, Presbyterian Healthcare Services, and New Mexico State Extension. We also want to

475 thank Gaby Phillips and Aracely Tellez for help with translating the survey into Spanish.

476 New York City: We would like to thank all the New Yorkers, including St. John's University and

477 its many community partners who participated in this study. Special thanks to the Vincentian

478 Institute for Social Action for sponsoring both studies.

479 NY State: Funded by the Natural Hazards Center, Quick Response Grant. The Quick Response 480 program is based on work supported by the National Science Foundation (Award \#1635593).

481 Any opinions, findings, conclusions, or recommendations expressed in this material are those of 482 the author(s) and do not necessarily reflect the views of NSF or the Natural Hazards Center.

483 NY Capital Region: Funding for the Qualtrics Panel Survey was provided by the Foundation for

484 Food and Agriculture Research. Funding for the non-Qualtrics Panel Survey was provided by

485 UAlbany President's COVID-19 MHD Engaged Researchers Seed Funding Program.

486 NY Central: Our team is very grateful to our partners at the Cornell Cooperative Extension

487 offices in Broome, Cortland, Cayuga, Onondaga, Oswego, and Seneca offices; to the NY 
medRxiv preprint doi: https://doi.org/10.1101/2021.07.23.21260280; this version posted July 25, 2021. The copyright holder for this preprint (which was not certified by peer review) is the author/funder, who has granted medRxiv a license to display the preprint in perpetuity.

It is made available under a CC-BY-NC-ND 4.0 International license .

Department of Environment and Conservation; and to all the others who helped with survey design, distribution, and applications of findings. We are also grateful to the survey respondents

490 themselves, and doubly so to those who volunteered and who are participating in follow up

491 interviews. This work was supported by a Cornell Atkinson Center COVID-19 Rapid Response

492 Fund award.

493 Utah: We would like to thank the Utah Create Better Health Program, Utah State University

494 Extension, and the Utah Department of Workforce Services for their support and assistance with

495 this project. We would also like to thank the Utah SNAP-eligible individuals who completed the 496 survey.

497 Vermont: We would like to thank many community partners for assisting with the dissemination

498 of the survey especially: Community College of Vermont, Farm to Institution New

499 England, Front Porch Forum, Hunger Free Vermont, Rural Vermont, Salvation Farms,

500 Support and Services at Home (SASH), VT Academy of Nutrition and Dietetics, VT

501 Department of Agriculture, VT Department of Children and Families, VT Department of Health,

502 VT Farm to Plate Network, VT Foodbank, VT Retail and Grocers Association, VT Sustainable

503 Jobs Fund. We would like to thank many community collaborations especially: Funding was

504 provided by The University of Vermont College of Agriculture and Life Sciences and Office of

505 the Vice President of Research, The Gund Institute for Environment, and the UVM ARS Food

506 Systems Research Center.

507 Washington: We wish to thank numerous community partners and stakeholders who helped

508 shape this project. Among those are: WA Department of Health, WA Department of Agriculture,

509 WA Anti-Hunger \& Nutrition Coalition, WA SNAP-Ed, KC Local Food Initiative, Northwest

510 Harvest, Washington State University (WSU) Extension, United Way of WA, and numerous food

511 banks, food pantries, charitable organizations community organizations, county health

512 departments, and local health jurisdictions. 
medRxiv preprint doi: https://doi.org/10.1101/2021.07.23.21260280; this version posted July 25, 2021. The copyright holder for this preprint (which was not certified by peer review) is the author/funder, who has granted medRxiv a license to display the preprint in perpetuity. It is made available under a CC-BY-NC-ND 4.0 International license .

\section{Author Contributions}

The research design, data collection, and analysis of individual site data was conducted by site-

517 level NFACT teams (see supplementary materials for all authors). A.W.B, L.A.C., M.M.D.,

518 M.T.N., G.A.P., M.S.R., S.R. R.S., and R.Z. wrote and edited the paper. M.T.N. conducted the

519 analysis comparing the study site types and food security prevalence. M.T.N. had primary

520 responsibility for final content. All authors read and approved the final manuscript.

\section{References}

522

1. World Health Organization (WHO). WHO Coronavirus (COVID-19) Dashboard. 2021.

2. World Health Organization (WHO). Timeline: WHO's COVID-19 Response. 2021 [cited; Available from: https://www.who.int/emergencies/diseases/novel-coronavirus-2019/interactivetimeline?gclid=Cj0KCQjw38-

DBhDpARIsADJ3kjn0CXSKxbndgAdwrXTCf1_VkG_S57hl4sbxqJ6SYw92H9JJlp3KrckaAs8FE ALw_wcB\#

3. Ahmad FB, Cisewski JA, Miniño A, Anderson RN. Provisional Mortality Data - United States, 2020; 2020 April 9, 2021.

4. Falk G, Carter JA, Nicchitta IA, Nyhof EC, Romero PD. Unemployment Rates During the COVID-19 Pandemic: In Brief. Congressional Research Service; 2021.

5. Center on Budget Policy and Priorities (CBPP). Tracking the COVID-19 Recession's Effects on Food, Housing, and Employment Hardships. 2021.

6. Center on Budget Policy and Priorities (CBPP). Chart Book: The Legacy of the Great Recession; 2019 June 6, 2019.

7. Chenarides L, Manfredo M, Richards TJ. COVID-19 and Food Supply Chains. Applied Economic Perspectives and Policy. 2020;43:270-9.

8. Loopstra R, Tarasuk V. Severity of household food insecurity is sensitive to change in household income and employment status among low-income families. J Nutr. 2013 Aug;143:1316-23.

9. Alesch DJ, Arendt LA, Holly JN. Managing for Long-Term Community Recovery in the Aftermath of Disaster: Public Entity Risk Institute; 2009.

10. Haas JE, Kates R, Bowden MJ. Reconstruction Following Disaster. Cambridge, MA and London, UK: The MIT Press; 1977.

11. Johnson LA, Hayashi H. Synthesis Efforts in Disaster Recovery Research. International Journal of Mass Emergencies \& Disasters. 2012;30:212-38.

12. Esnard AM, Sapat A. Population/Community Displacement. Handbook of Disaster Research: Springer, Cham; 2018. p. 431-46.

13. Coleman-Jensen A, Rabbitt MP, Gregory CA, Singh A. Household Food Security in the United States in 2018: United States Department of Agriculture (USDA) Economic Research Service; 2019.

14. Thomas DSK, Phillips BD, Lovekamp WE, Fothergill A. Social Vulnerability to Disasters: CRC Press; 2013. 
medRxiv preprint doi: https://doi.org/10.1101/2021.07.23.21260280; this version posted July 25, 2021. The copyright holder for this preprint (which was not certified by peer review) is the author/funder, who has granted medRxiv a license to display the preprint in perpetuity. It is made available under a CC-BY-NC-ND 4.0 International license .

555

556

557

558

559

560

561

562

563

564

565

566

567

568

569

570

571

572

573

574

575

576

577

578

579

580

581

582

583

584

585

586

587

588

589

590

591

592

593

594

595

596

597

598

599

600

601

602

603

604

605

15. Wolfson JA, Leung CW. Food Insecurity During COVID-19: An Acute Crisis With LongTerm Health Implications. American Journal of Public Health. 2020;110:1763-5.

16. United Nations Food and Agriculture Organization (FAO). An Introduction to the Basic Concepts of Food Security; 2008.

17. Clay LA, Papas MA, Gill KB, Abramson DM. Factors Associated with Continued Food Insecurity among Households Recovering from Hurricane Katrina. International Journal of Environmental Research and Public Health. 2018;15:1647.

18. Nord M, Coleman-Jensen A, Andrews M, Carlson S. Household Food Security in the United States, 2009: United States Department of Agriculture (USDA) Economic Research Service; 2010.

19. Marchione TJ. Foods provided through U.S. Government Emergency Food Aid Programs: policies and customs governing their formulation, selection and distribution. J Nutr. 2002 Jul;132:2104S-11S.

20. Clay LA, Ross AD. Factors Associated with Food Insecurity Following Hurricane Harvey in Texas. International Journal of Environmental Research and Public Health. 2020;17:762.

21. (FRAC). FRaAC. Definiting food insecurity and mearuting it during COVID-19. 2021.

22. Feeding America. The impact of the coronavirus on food security in 2020 \& 2021; 2021.

23. Gundersen C, Hake M, Dewey A, Engelhard E. Food Insecurity during COVID-19.

Applied Economic Perspectives and Policy. 2021;43:153-61.

24. Fitzpatrick KM, Harris C, Drawve G, Willis DE. Assessing Food Insecurity Among US

Adults During the COVID-19 Pandemic. Journal of Hunger and Environmental Nutrition. 2021;16:1-18.

25. Christian P. Impact of the economic crisis and increase in food prices on child mortality: exploring nutritional pathways. J Nutr. 2010 Jan;140:177S-81S.

26. United States Census Bureau. Measuring household experiences during the coronavirus pandemic. 2021.

27. Niles MT, Neff R, Biehl E, Bertmann F, Morgan EH, Wentworth T. Food Access and Security During Coronavirus Survey- Version 1.0. V2 ed: Harvard Dataverse; 2020.

28. Niles MT, Bertmann F, Belarmino EH, Wentworth T, Biehl E, Neff R. The Early Food Insecurity Impacts of COVID-19. Nutrients. 2020 Jul 15;12.

29. Niles MT, Neff R, Biehl E, Bertmann F, Belarmino EH, Acciai F, Ohri-Vachaspati P. Food Access and Food Security During COVID-19 Survey- Version 2.1. V3 ed: Harvard Dataverse; 2020.

30. United States Department of Agriculture Economic Research Service. U.S. household food security survey module: six-item short form. 2012 [cited 18-Jun-2021]; Available from: https://www.ers.usda.gov/topics/food-nutrition-assistance/food-security-in-the-us/surveytools/\#six

31. 2019. S. Stata Statistical Software: Release 16. College Station, TX: StataCorp LLC. 2019.

32. Jaccard J, Becker MA, Wood G. Pairwise multiple comparison procedures: A review. Psychological Bulletin. 1984;96:589-96.

33. Schanzenbach D, Pitts A. Food Insecurity During COVID-19 in Households with Children: Results by Racial and Ethnic Groups: Institute for Policy Research, Northwestern University; 2020 July 9, 2020.

34. Schanzenbach D, Pitts A. Food Insecurity in the Census Household Pulse Survey Data Tables: Institute for Policy Research, Northwestern University; 2020 June 1, 2020.

35. Rocco P, Béland D, Waddan A. Stuck in neutral? Federalism, policy instruments, and counter-cyclical responses to COVID-19 in the United States. Policy and Society. 2020;39:45877.

36. USDA-FNS. SNAP: COVID-19 Waivers by State. 2021 [cited; Available from: https://www.fns.usda.gov/disaster/pandemic/COVID-19/snap-waivers-flexibilities 
medRxiv preprint doi: https://doi.org/10.1101/2021.07.23.21260280; this version posted July 25, 2021. The copyright holder for this preprint (which was not certified by peer review) is the author/funder, who has granted medRxiv a license to display the preprint in perpetuity. It is made available under a CC-BY-NC-ND 4.0 International license .

606

607

608

609

610

611

612

613

614

615

616

617

618

619

620

621

622

623

624

625

626

627

628

629

630

631

632

633

634

635

37. Schanzenbach D, Pitts A. Estimates of Food Insecurity During the COVID-19 Crisis:

Results from the COVID Impact Survey, Week 1 (April 20-26, 2020): Institute for Policy Research, Northwestern University; 2020 May 13, 2020.

38. Perry BL, Aronson B, Pescosolido BA. Pandemic Precarity: COVID-19 Is Exposing and Exacerbating Inequalities in the American Heartland. Proceedings of the National Academy of Sciences of the United States of America. 2021 February 23, 2021;118.

39. Swinburne M. Chapter 28: Using SNAP to Address Food Insecurity During the COVID19 Pandemic. In: Burris S, de Guia S, Gable L, Levin DE, Parmet WE, Terry NP, editors. COVID-19 Policy Playbook: Legal Recommendations for a Safer, More Equitable Future. Boston: Public Health Law Watch; 2021. p. 170-3.

40. Bauer L, Broady K, Edelberg W, O'Donnell J. Ten Facts About COVID-19 and the U.S. Economy: Brookings; 2020 September 17, 2020.

41. Ohri-Vachaspati P, Acciai F, Martinelli S, Harper K, Bertmann FM, Belarmino E, Neff R, Niles M. Food Assistance Program Participation among US Households during the COVID-19 Pandemic. 2020.

42. Berkowitz SA, Basu S. Unmet Social Needs And Worse Mental Health After Expiration Of COVID-19 Federal Pandemic Unemployment Compensation. Health Affairs. 2021;40:426-34. 43. Hernandez DC, Holtzclaw LE. Commentary: The Impact of the COVID-19 Pandemic and the Economic Recession on Food Insecurity: Short- and Long-term Recommendations to Assist Families and Communities. Family and Community Health. 2021;44:84-6.

44. Clay LA, Papas MA, Gill KB, Abramson DM. Application of a Theoretical Model Toward Understanding Continued Food Insecurity Post Hurricane Katrina. Disaster Medicine and Public Health Preparedness. 2018;12:47-56.

45. Njai R, Siegel P, Yin S, Liao Y. Prevalence of Perceived Food and Housing Security 15 States, 2013; 2017 January 13, 2017. Report No.: 66.

46. Kelfve S, Kivi M, Johansson B, Lindwall M. Going web or staying paper? The use of web-surveys among older people. BMC Med Res Methodol. 2020 Oct 8;20:252.

47. Pew Research Center al. Demographics of Internet and Home Broadband Usage in the United States. 2021.

48. Perrin A. Digital Gap between Rural and Nonrural America Persists; 2019. 
Table 1. Study sites and relevant methods for each site.

\begin{tabular}{|c|c|c|c|c|c|}
\hline Study Site & Target population & Sample and Recruitment & Weighting & $\begin{array}{l}\text { Representative } \\
\text { of State }\end{array}$ & Dates in Field \\
\hline Alabama & General population & $\begin{array}{l}\text { Convenience sample. Recruitment via social } \\
\text { media and community organizations }\end{array}$ & No weighting & No & June-July 2020 \\
\hline Arizona & General population & $\begin{array}{l}\text { Representative sample with survey panel (on } \\
\text { race, ethnicity) with oversampling of low-income } \\
\text { population with Qualtrics }\end{array}$ & $\begin{array}{l}\text { Weighted on } \\
\text { income }\end{array}$ & Yes & July-August 2020 \\
\hline California- Bay Area & General population & $\begin{array}{l}\text { Convenience sample. Recruitment via social } \\
\text { media and community organizations }\end{array}$ & No weighting & No & $\begin{array}{l}\text { August- } \\
\text { November } 2020\end{array}$ \\
\hline Chicago/ Illinois & $\begin{array}{l}\text { High-risk } \\
\text { population }\end{array}$ & $\begin{array}{l}\text { High-risk sample. Survey panel sampling with } \\
\text { Qualtrics to meet specific race, ethnicity, } \\
\text { income and education quotas. Oversampled } \\
\text { low-income population (50\%), Black (50\%), } \\
\text { Hispanic (50\%) and } 50 \% \text { high school education } \\
\text { or less }\end{array}$ & No weighting & No & June-July 2020 \\
\hline Connecticut & $\begin{array}{l}\text { Oversampled low- } \\
\text { income population }\end{array}$ & $\begin{array}{l}\text { High-risk sample. Survey panel with } \\
\text { oversampled low-income population, but } \\
\text { representative on race and ethnicity with } \\
\text { Qualtrics }\end{array}$ & No weighting & No & August 2020 \\
\hline Maine & General population & $\begin{array}{l}\text { Representative sample with survey panel } \\
\text { (income) with Qualtrics }\end{array}$ & No weighting & Yes & $\begin{array}{l}\text { August- } \\
\text { September } 2020\end{array}$ \\
\hline Maryland & General population & $\begin{array}{l}\text { Representative sample with survey panel (on } \\
\text { race, ethnicity and income) with Qualtrics }\end{array}$ & No weighting & Yes & $\begin{array}{l}\text { July-September } \\
2020\end{array}$ \\
\hline Massachusetts & General population & $\begin{array}{l}\text { Representative sample with survey panel (on } \\
\text { race, ethnicity, education, age, gender, } \\
\text { geographic region) with oversampling of low- } \\
\text { income population with Qualtrics }\end{array}$ & $\begin{array}{l}\text { Weighted on } \\
\text { household income, } \\
\text { age, gender, } \\
\text { race/ethnicity, } \\
\text { education, } \\
\text { geographic region }\end{array}$ & Yes & $\begin{array}{l}\text { October } 2020 \text { - } \\
\text { January } 2021\end{array}$ \\
\hline Michigan & General population & $\begin{array}{l}\text { Convenience sample. Recruitment via social } \\
\text { media }\end{array}$ & No weighting & No & June -June 2020 \\
\hline National & General population & $\begin{array}{l}\text { Representative sample with survey panel (on } \\
\text { race, ethnicity) and oversampling of low-income } \\
\text { population with Qualtrics }\end{array}$ & $\begin{array}{l}\text { Weighted on } \\
\text { income }\end{array}$ & Yes & July-August 2020 \\
\hline New Mexico & General population & $\begin{array}{l}\text { Convenience sample. Recruitment via social } \\
\text { media and community organizations }\end{array}$ & No weighting & No & May-June 2020 \\
\hline $\begin{array}{l}\text { New York City (May/ } \\
\text { June) }\end{array}$ & $\begin{array}{l}\text { High-risk } \\
\text { population }\end{array}$ & $\begin{array}{l}\text { High-risk sample. Nested quota via social media } \\
\text { campaign, community-based organizations, } \\
\text { convenience sample, and survey consumer } \\
\text { panel sampling via Qualtrics to meet specific } \\
\text { race/ethnicity, income and education quotas. } \\
\text { This includes an oversampling of Blacks (50\%), }\end{array}$ & No weighting & No & May-June 2020 \\
\hline
\end{tabular}


Hispanics (50\%), high school education or less $(50 \%)$, and low income (50\% below $\$ 25,000$ annual income before taxes).

\begin{tabular}{|c|c|c|c|c|c|}
\hline $\begin{array}{l}\text { New York City (July/ } \\
\text { August) }\end{array}$ & $\begin{array}{l}\text { High-risk } \\
\text { population }\end{array}$ & $\begin{array}{l}\text { High-risk sample. Non-proportional quota } \\
\text { sample, recruited by Qualtrics. Oversampled } \\
\text { low-income population ( } 50 \%) \text {, Black }(40 \% \text {, } \\
\text { Hispanic ( } 40 \%) \text {, Native American }(20 \%) \text { and } \\
50 \% \text { high school education or less. }\end{array}$ & No weighting & No & July-August 2020 \\
\hline NY State except NYC & $\begin{array}{l}\text { High-risk } \\
\text { population }\end{array}$ & $\begin{array}{l}\text { High-risk sample. Non--proportional quota } \\
\text { sample recruited by Qualtrics. Quotas: low- } \\
\text { income or low-education (50\%), Black (50\%) } \\
\text { and Hispanic }(50 \%) \text {. }\end{array}$ & No weighting & No & $\begin{array}{l}\text { July-September } \\
2020\end{array}$ \\
\hline $\begin{array}{l}\text { NY- Capital Region (Oct- } \\
\text { Jan) }\end{array}$ & General population & $\begin{array}{l}\text { Representative sample with survey panel (on } \\
\text { race, ethnicity and income) with Qualtrics }\end{array}$ & No weighting & Yes & $\begin{array}{l}\text { October 2020- } \\
\text { January } 2021\end{array}$ \\
\hline $\begin{array}{l}\text { NY- Capital } \\
\text { Region (Jan/Feb) }\end{array}$ & General population & $\begin{array}{l}\text { Convenience sample. Recruitment via social } \\
\text { media and community organizations }\end{array}$ & No weighting & No & $\begin{array}{l}\text { January- } \\
\text { February } 2021\end{array}$ \\
\hline NY Central / Upstate & General population & $\begin{array}{l}\text { Convenience sample. Recruitment via listservs, } \\
\text { social media, community organizations }\end{array}$ & No weighting & No & $\begin{array}{l}\text { October- } \\
\text { December } 2020 \\
\end{array}$ \\
\hline Utah & $\begin{array}{l}\text { High-risk } \\
\text { population }\end{array}$ & $\begin{array}{l}\text { Convenience sample. Recruited Supplemental } \\
\text { Nutrition Assistance Program (SNAP) } \\
\text { participants through state list-serv of current } \\
\text { SNAP recipients }\end{array}$ & No weighting & No & $\begin{array}{l}\text { July-September } \\
2020\end{array}$ \\
\hline Vermont (March/ April) & General population & $\begin{array}{l}\text { Convenience sample. Recruitment via listservs, } \\
\text { social media, community organizations }\end{array}$ & No weighting & No & March-April 2020 \\
\hline Vermont (May/June)† & General population & $\begin{array}{l}\text { Convenience sample. Recruitment via listservs, } \\
\text { social media, community organizations }\end{array}$ & No weighting & No & May- June 2020 \\
\hline Vermont (August/ Sept) & General population & $\begin{array}{l}\text { Representative sample with survey panel (on } \\
\text { race, ethnicity and income) with Qualtrics }\end{array}$ & No weighting & Yes & $\begin{array}{l}\text { July-September } \\
2020\end{array}$ \\
\hline $\begin{array}{l}\text { Washington State } \\
\text { (June/July) }\end{array}$ & General population & $\begin{array}{l}\text { Convenience sample. Recruitment via listservs, } \\
\text { social media, community organizations }\end{array}$ & No weighting & No & June-July 2020 \\
\hline $\begin{array}{l}\text { Washington State } \\
\text { (Dec/Jan) }\end{array}$ & General population & $\begin{array}{l}\text { Convenience sample. Recruitment via listservs, } \\
\text { social media, community organizations, } \\
\text { recontact of wave respondents }\end{array}$ & No weighting & No & $\begin{array}{l}\text { December } 2020- \\
\text { January } 2021\end{array}$ \\
\hline Wisconsin & General population. & $\begin{array}{l}\text { Representative sample with survey panel (on } \\
\text { race, ethnicity and income) with Qualtrics. } \\
\text { Oversample Milwaukee area. }\end{array}$ & No weighting & Yes & $\begin{array}{l}\text { July-October } \\
2020\end{array}$ \\
\hline
\end{tabular}

+ Longitudinal sample of a subset of the same people who responded to the Vermont March/April survey 
Table 2. Total number of respondents and sub-population characteristics by study site.

\begin{tabular}{|c|c|c|c|c|c|c|c|c|}
\hline Study Site & $\begin{array}{l}\text { Total } \\
\text { Respondents }^{1}\end{array}$ & $\begin{array}{l}\text { With } \\
\text { Children }\end{array}$ & $\begin{array}{l}\text { Job Disruption/ } \\
\text { (Reduced } \\
\text { Income) }\end{array}$ & $\mathrm{BIPOC}^{2}$ & $\mathrm{NHW}^{3}$ & $\mathrm{NHB}^{4}$ & Hispanic & $\begin{array}{l}\text { Other or } \\
\text { Multiple } \\
\text { Races }\end{array}$ \\
\hline Alabama & 1247 & 541 & 546 & 226 & 1061 & 142 & 27 & 86 \\
\hline Arizona & 576 & 189 & 221 & 268 & 352 & 32 & 194 & 42 \\
\hline California- Bay Area & 724 & 620 & 321 & 232 & 223 & 6 & 122 & 49 \\
\hline Chicago/ Illinois & 680 & 379 & 314 & 498 & 169 & 215 & 258 & 103 \\
\hline Connecticut & 512 & 199 & 286 & 158 & 354 & 56 & 73 & 54 \\
\hline Maine & 504 & 97 & 193 & 42 & 477 & 9 & 8 & 8 \\
\hline Maryland & 903 & 330 & 368 & 427 & 555 & 239 & 91 & 97 \\
\hline Massachusetts & 2939 & 1098 & 1467 & 748 & 2191 & 202 & 292 & 254 \\
\hline Michigan & 484 & 237 & 279 & 64 & 418 & 25 & 18 & 21 \\
\hline National & 1510 & 515 & 568 & 585 & 925 & 212 & 255 & 118 \\
\hline New Mexico & 1415 & 406 & 261 & 494 & 843 & 15 & 362 & 117 \\
\hline $\begin{array}{l}\text { New York City (May/ } \\
\text { June) }\end{array}$ & 1,165 & 599 & 494 & 876 & 289 & 252 & 496 & 128 \\
\hline $\begin{array}{l}\text { New York City } \\
\text { (July/August) }\end{array}$ & 525 & 317 & 285 & 484 & 41 & 154 & 123 & 102 \\
\hline NY State & 494 & 207 & 189 & 494 & $\mathrm{n} / \mathrm{a}$ & 260 & 234 & \\
\hline $\begin{array}{l}\text { NY -Capital Region } \\
\text { (Oct-Jan) }\end{array}$ & 479 & 167 & 294 & 156 & 353 & 43 & 42 & 71 \\
\hline $\begin{array}{l}\text { NY-Capital Region } \\
\text { (Jan-Feb) }\end{array}$ & 427 & 283 & 327 & 137 & 317 & 62 & 56 & 19 \\
\hline NY- Central/Upstate & 434 & 120 & 144 & 30 & 380 & 2 & 10 & 22 \\
\hline Utah & 644 & 219 & 277 & 102 & 392 & 12 & 61 & 56 \\
\hline $\begin{array}{l}\text { Vermont (March } \\
\text { /April) }\end{array}$ & 3016 & 913 & 1103 & 150 & 2603 & 5 & 45 & 104 \\
\hline $\begin{array}{l}\text { Vermont (May/ } \\
\text { June) }\end{array}$ & 1212 & 383 & 294 & 57 & 1137 & 3 & 19 & 37 \\
\hline $\begin{array}{l}\text { Vermont (August/ } \\
\text { Sept) }\end{array}$ & 578 & 178 & 270 & 49 & 551 & 6 & 17 & 26 \\
\hline $\begin{array}{l}\text { Washington State } \\
\text { (June/July) }\end{array}$ & 2514 & 1095 & 636 & 592 & 1910 & 93 & 210 & 289 \\
\hline $\begin{array}{l}\text { Washington State } \\
\text { (Dec/Jan) }\end{array}$ & 3169 & 1541 & 343 & 737 & 2647 & 98 & 283 & 356 \\
\hline Wisconsin & 1017 & 393 & 430 & 181 & 836 & 58 & 80 & 43 \\
\hline
\end{tabular}




\begin{tabular}{|c|c|c|c|c|c|c|c|c|}
\hline Study Site & $\begin{array}{l}\text { Total } \\
\text { Respondents }\end{array}$ & $\begin{array}{l}\text { With } \\
\text { Children }\end{array}$ & $\begin{array}{l}\text { Job Disruption/ } \\
\text { (Reduced } \\
\text { Income) }\end{array}$ & $\mathrm{BIPOC}^{2}$ & $\mathrm{NHW}^{3}$ & $\mathrm{NHB}^{4}$ & Hispanic & $\begin{array}{l}\text { Other or } \\
\text { Multiple } \\
\text { Races }\end{array}$ \\
\hline TOTAL & 27168 & 11026 & 9589 & 7787 & 19024 & 2195 & 3235 & 2202 \\
\hline$\%$ of total & & $40.6 \%$ & $35.3 \%$ & $28.7 \%$ & $70.0 \%$ & $8.1 \%$ & $11.9 \%$ & $8.1 \%$ \\
\hline
\end{tabular}

1 Indicates number of total respondents with food security data

2 Black, Indigenous, People of Color respondents. Number includes anyone identifying as other than non-Hispanic white.

3 Non-Hispanic White (NHW)

4 Non-Hispanic Black (NHB) 
Table 3. Overall prevalence of food insecurity across different measures and time periods by survey type. P values that are statistically significant $(p<0.05)$ are lightly shaded for emphasis, and were obtained through ANOVAs with Scheffe multiple comparisons.

\begin{tabular}{|c|c|c|c|c|c|c|c|}
\hline & & \multicolumn{3}{|c|}{ Survey Type } & \multicolumn{3}{|c|}{$\mathrm{P}$ Values } \\
\hline $\begin{array}{l}\text { Prevalence of } \\
\text { Food Insecurity }\end{array}$ & Timeframe & Convenience & $\begin{array}{c}\text { State } \\
\text { Representative }\end{array}$ & High Risk & $\begin{array}{c}\text { Convenience- } \\
\text { High Risk }\end{array}$ & $\begin{array}{l}\text { Convenience- } \\
\text { Representative }\end{array}$ & $\begin{array}{c}\text { Representative-High } \\
\text { Risk }\end{array}$ \\
\hline \multirow{3}{*}{$\begin{array}{l}\text { Overall Food } \\
\text { Insecurity }\end{array}$} & Before COVID-19 & $21.8 \%$ & $23.9 \%$ & $43.6 \%$ & 0.002 & 0.918 & 0.004 \\
\hline & Since COVID-19 & $30.2 \%$ & $32.1 \%$ & $54.3 \%$ & 0.000 & 0.933 & 0.002 \\
\hline & Percent Change & $36.9 \%$ & $34.7 \%$ & $26.9 \%$ & 0.561 & 0.971 & 0.701 \\
\hline \multirow{3}{*}{$\begin{array}{l}\text { BIPOC Food } \\
\text { Insecurity }\end{array}$} & Before COVID-19 & $29.5 \%$ & $32.1 \%$ & $37.3 \%$ & 0.211 & 0.818 & 0.497 \\
\hline & Since COVID-19 & $40.2 \%$ & $40.6 \%$ & $55.1 \%$ & 0.048 & 0.999 & 0.078 \\
\hline & Percent Change & $32.0 \%$ & $29.5 \%$ & $36.0 \%$ & 0.892 & 0.957 & 0.743 \\
\hline \multirow{3}{*}{$\begin{array}{c}\text { Households } \\
\text { with Children } \\
\text { Food Insecurity }\end{array}$} & Before COVID-19 & $30.1 \%$ & $37.2 \%$ & $44.1 \%$ & 0.042 & 0.389 & 0.424 \\
\hline & Since COVID-19 & $39.0 \%$ & $49.2 \%$ & $57.6 \%$ & 0.003 & 0.117 & 0.272 \\
\hline & Percent Change & $31.8 \%$ & $33.4 \%$ & $32.7 \%$ & 0.995 & 0.983 & 0.997 \\
\hline \multirow{4}{*}{$\begin{array}{l}\text { Job Disruption } \\
\text { Food Insecurity }\end{array}$} & Any Job & & & & & & \\
\hline & Disruption & $43.5 \%$ & $50.1 \%$ & $64.8 \%$ & 0.003 & 0.489 & 0.058 \\
\hline & Job Loss & $51.3 \%$ & $60.8 \%$ & $72.1 \%$ & 0.003 & 0.216 & 0.168 \\
\hline & Furlough & $44.2 \%$ & $51.2 \%$ & $63.1 \%$ & 0.081 & 0.679 & 0.383 \\
\hline
\end{tabular}




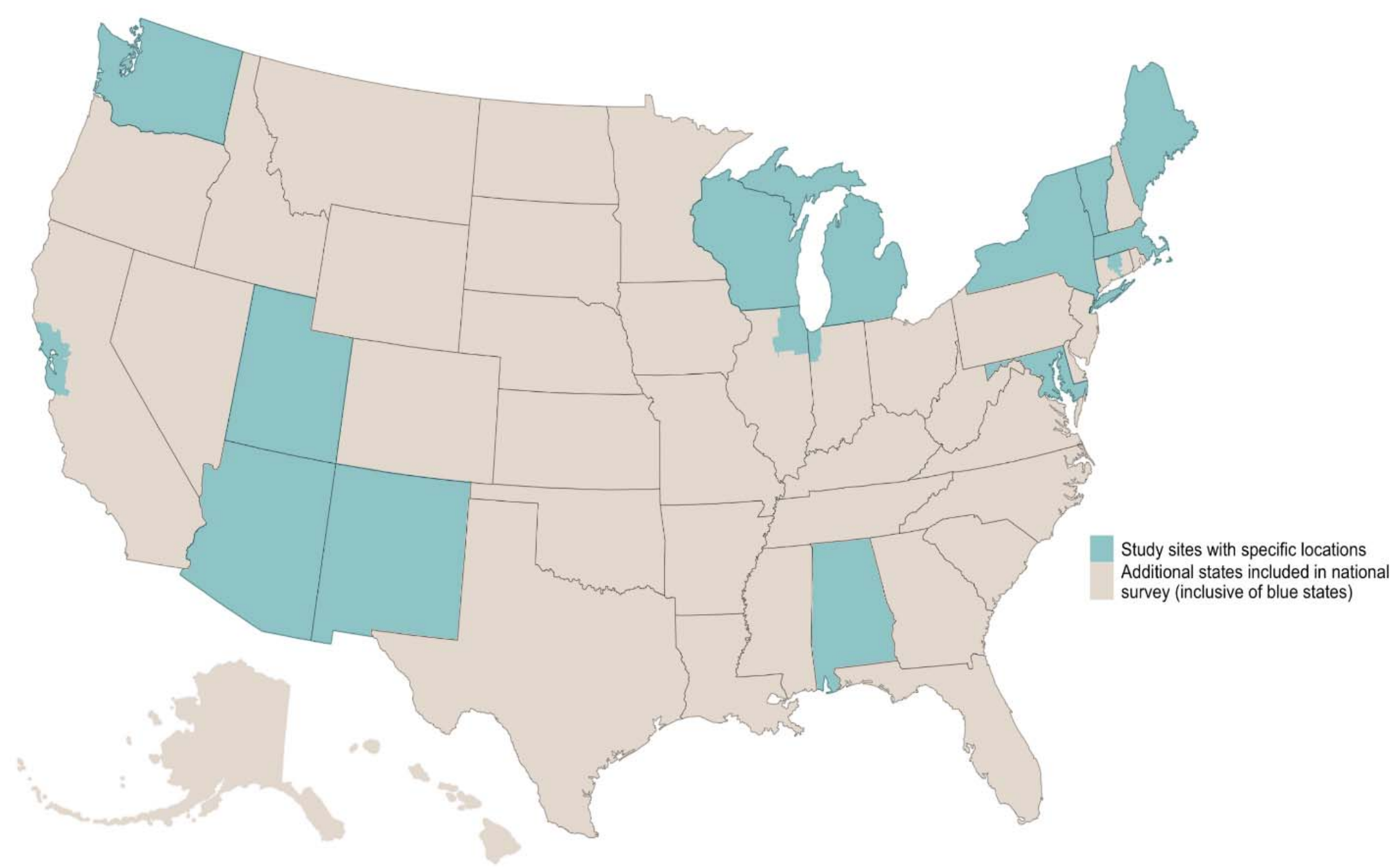

Figure 1. NFACT study sites. Blue states and regions represent sites in addition to the national sample strategy, which includes additional data from all states. Visual credit: Samuel F. Rosenblatt 
Before COVID-19 $\square$ Since COVID-19 Percent Change

\begin{tabular}{|c|c|c|c|}
\hline & Before COVID-19 & Since COVID-19 & Percent Change \\
\hline Arizona & $25.4 \%$ & $32.5 \%$ & $28.0 \%$ \\
\hline Maine & $25.2 \%$ & $34.1 \%$ & $35.3 \%$ \\
\hline Maryland & $21.8 \%$ & $28.8 \%$ & $31.9 \%$ \\
\hline Massachusetts & $19.2 \%$ & $29.8 \%$ & $55.2 \%$ \\
\hline National & $25.3 \%$ & $34.0 \%$ & $34.4 \%$ \\
\hline NY-Capital Region (Oct-Jan) & $30.1 \%$ & $40.5 \%$ & $34.6 \%$ \\
\hline Vermont (August/Sept) & $22.5 \%$ & $29.0 \%$ & $28.9 \%$ \\
\hline Wisconsin & $28.0 \%$ & $36.2 \%$ & $29.3 \%$ \\
\hline Alabama & $24.9 \%$ & $38.3 \%$ & $53.8 \%$ \\
\hline California- Bay Area & $20.0 \%$ & $33.0 \%$ & $65.0 \%$ \\
\hline Michigan & & $36.2 \%$ & \\
\hline New Mexico & $30.0 \%$ & $30.0 \%$ & $0.0 \%$ \\
\hline NY-Capital Region (Jan/Feb) & $35.1 \%$ & $53.7 \%$ & $52.8 \%$ \\
\hline NY Upstate/Central & $7.4 \%$ & $10.8 \%$ & $45.9 \%$ \\
\hline Vermont (March/April) & $18.0 \%$ & $24.0 \%$ & $33.3 \%$ \\
\hline Vermont (May/June) & $17.4 \%$ & $18.7 \%$ & $7.5 \%$ \\
\hline Washington (June/July) & & $30.0 \%$ & \\
\hline Washington (Dec/January) & & $26.9 \%$ & \\
\hline \multirow{6}{*}{$\begin{array}{l}\text { Chicago/Illinois } \\
\text { Greater Hartford Connecticut } \\
\text { New York City (May/June) } \\
\text { New York City (July/August) } \\
\text { NY State }\end{array}$} & $42.0 \%$ & $46.0 \%$ & $9.5 \%$ \\
\hline & $34.5 \%$ & $45.7 \%$ & $32.5 \%$ \\
\hline & $43.3 \%$ & $56.7 \%$ & $30.9 \%$ \\
\hline & $66.1 \%$ & $73.9 \%$ & $11.8 \%$ \\
\hline & $33.1 \%$ & $48.4 \%$ & $46.4 \%$ \\
\hline & $55.9 \%$ & $68.7 \%$ & $22.9 \%$ \\
\hline
\end{tabular}

Figure 2. Overall prevalence of food insecurity across NFACT surveys and study sites. 
Before COVID-19 $\square$ Since COVID-19 $\square$ Percent Change

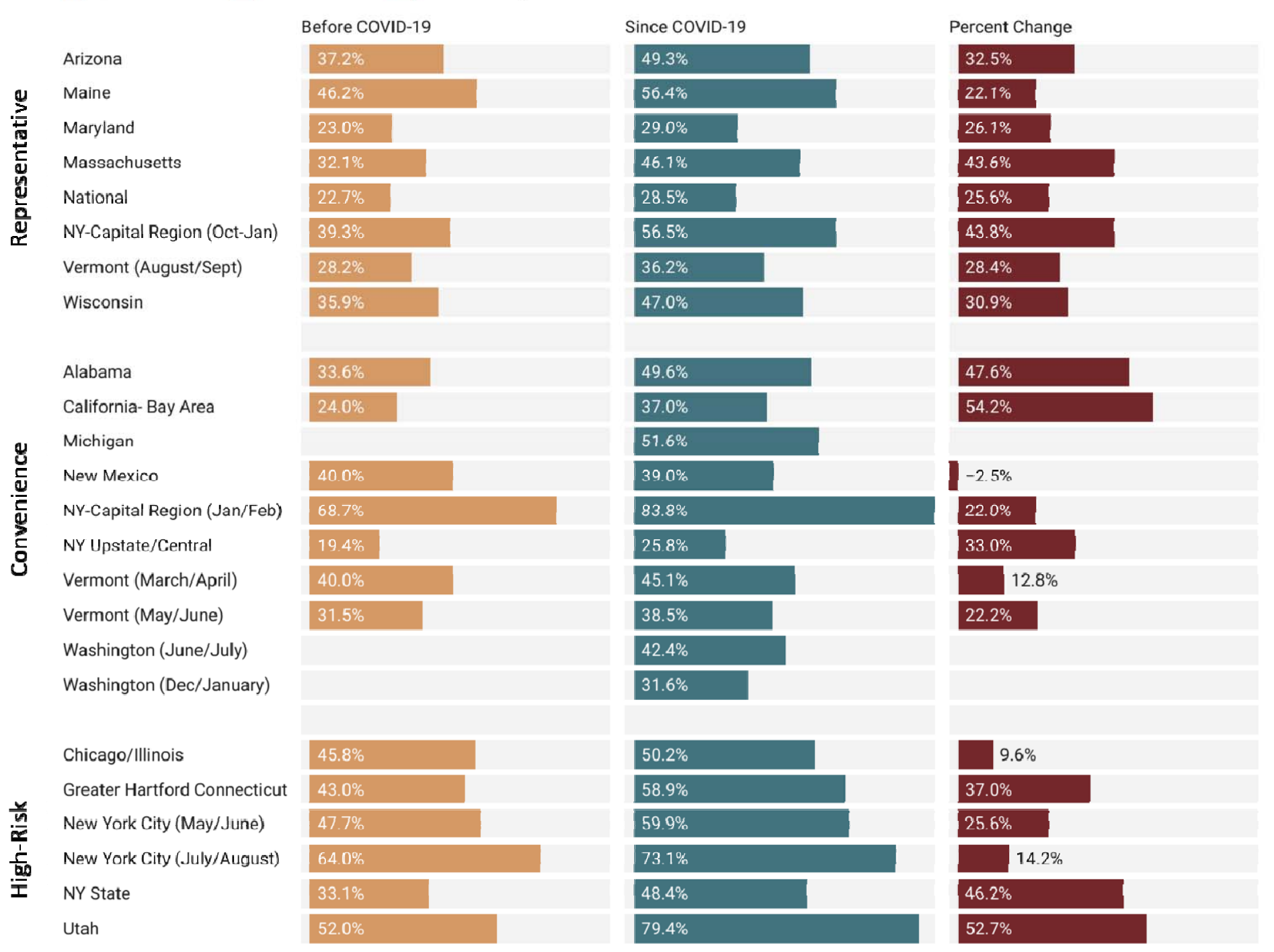

Figure 3. Prevalence of food insecurity before and during the COVID-19 pandemic, and the percent change, among BIPOC respondents, by study site. 


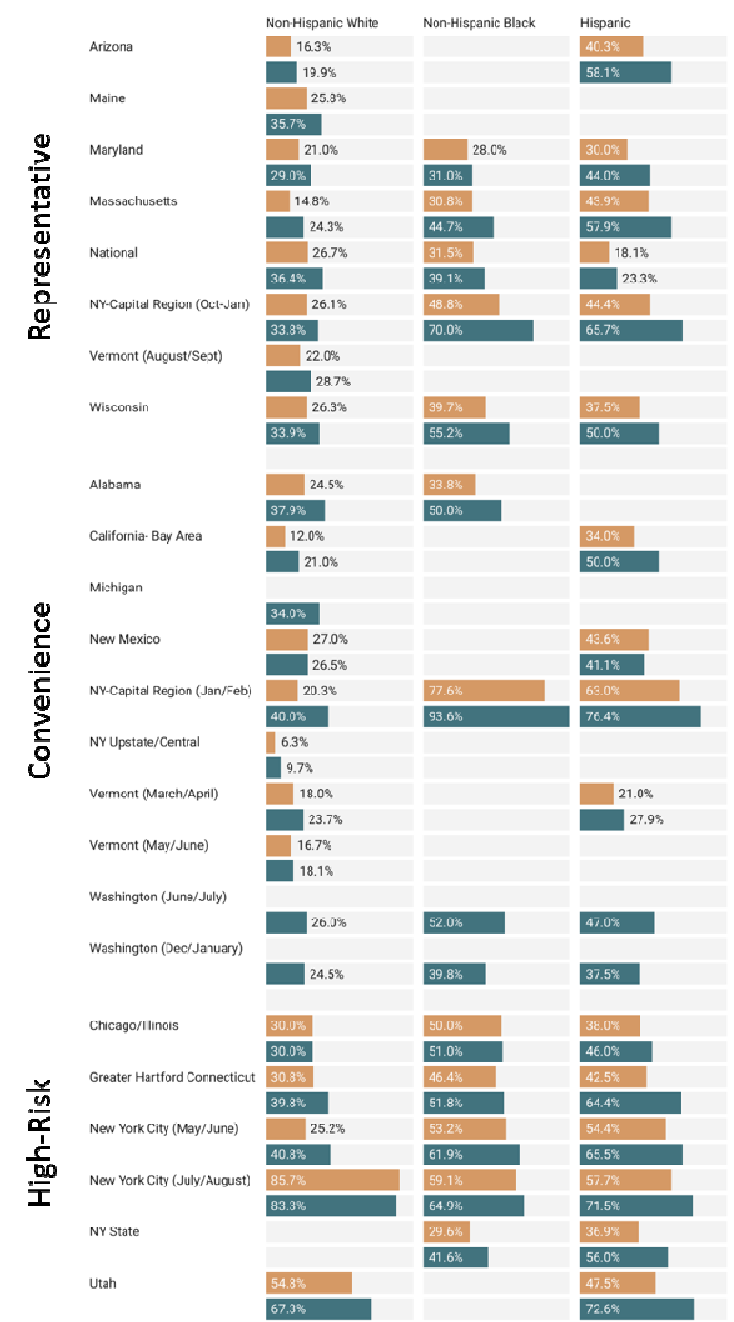

Figure 4. Prevalence of food insecurity before and during the COVID-19 pandemic, and the percent change, among different racial and ethnic groups, by study site. Disaggregated race and ethnicity food insecurity prevalence is only reported for sites where at least 30 respondents identified as a specific race or ethnic group. 
Before COVID-19 Since COVID-19 $\square$ Percent Change

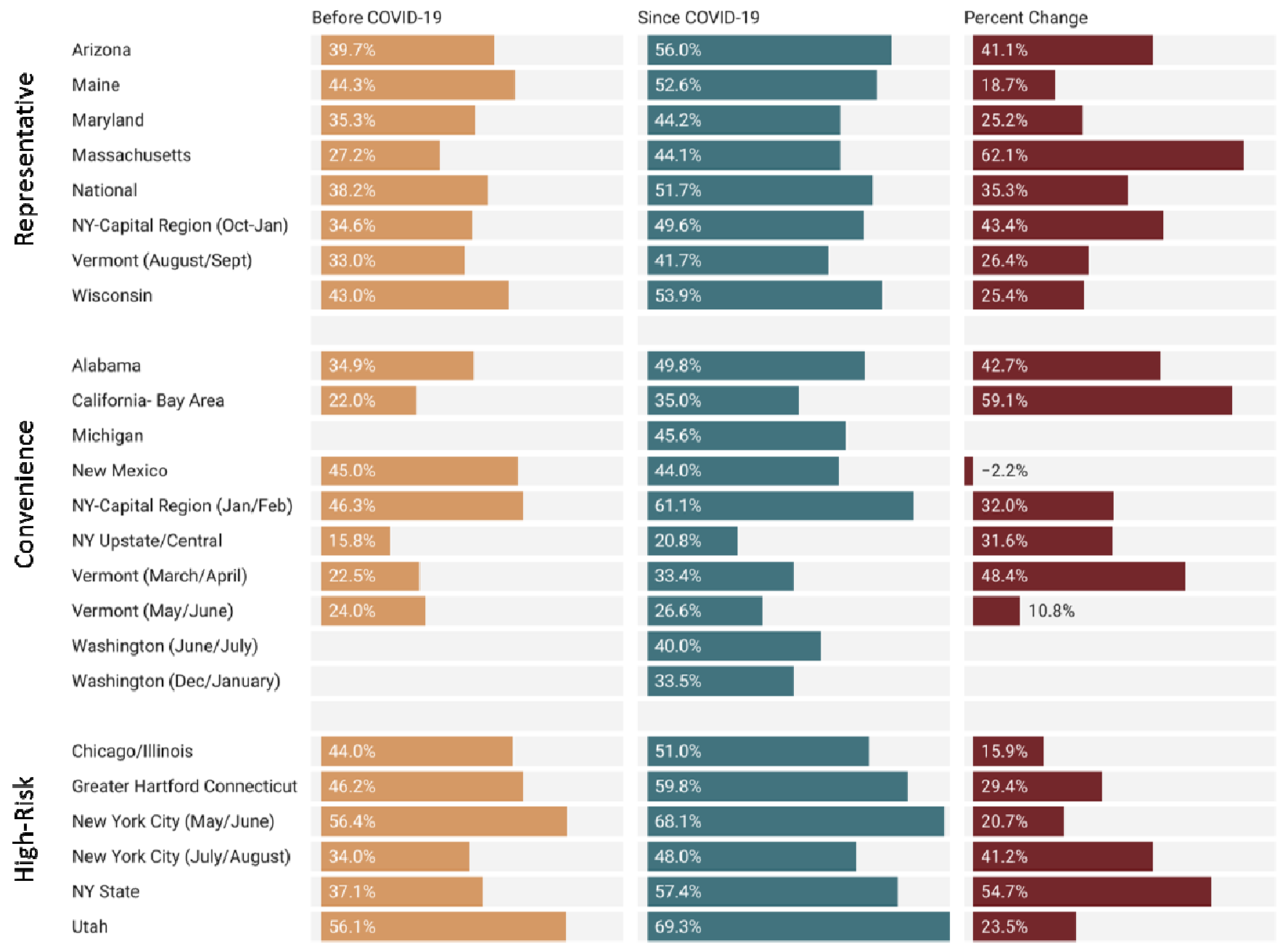

Figure 5. Prevalence of food insecurity before and during the COVID-19 pandemic among households with children in a study site, and the percent change.

Page 36 of 38 


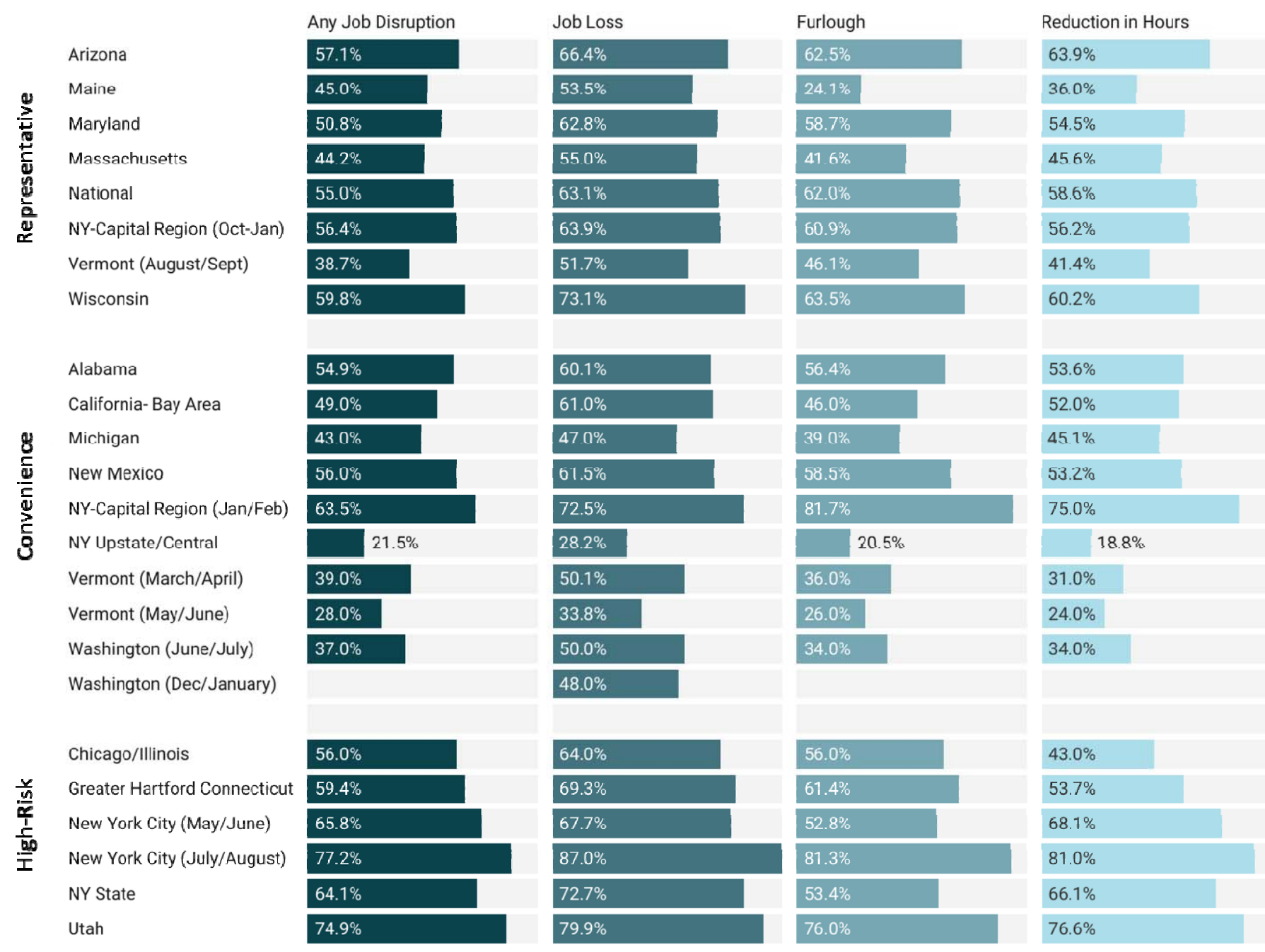

Figure 6. Prevalence of food insecurity since the COVID-19 pandemic among respondents with any job disruption, job loss, furlough, and/or reduction in hours, by study site. 
Page 38 of 38

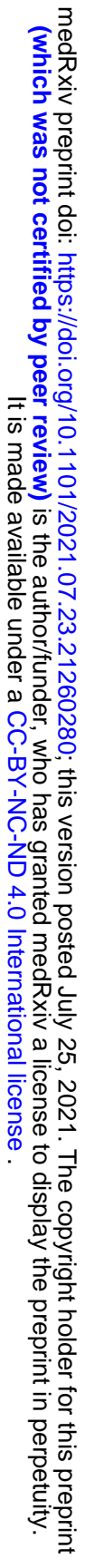

